\title{
An Overview of the Bathymetry and Geomorphology of the Tanzania EEZ
}

\author{
D.C.P. Masalu*
}

Institute of Marine Sciences, University of Dar es Salaam, P.O. Box 668, Zanzibar, Tanzania

\begin{abstract}
Bathymetry is one of the basic data for many studies in coastal and marine environments. It influences many of the coastal and oceanographic processes, and can explain the origin of some of the seafloor features. Knowledge of the bathymetry is important for navigation, planning of research, delineation of maritime boundaries and delineation of specific submarine ecosystems such as canyons. Despite its importance very little has done to map the Tanzania Economic Exclusive Zone (EEZ), as is evidenced by the scarcity of locally collected bathymetric data. The lack of basic ocean capability is a major challenge that Tanzania must overcome, to make effective planning and utilization of the coastal and marine resources. It will also enable Tanzania to access other opportunities such as extension of its continental shelf limits. Based on the global database used in this study three distinct features i.e., an isolated seamount located at $5.1^{\circ} \mathrm{S} / 41.7^{\circ} \mathrm{E}$, a ridge located at south near $41.5^{\circ} \mathrm{E}$, and a depression located at $41.0^{\circ} \mathrm{E} / 9.5^{\circ} \mathrm{S}$, were identified on the Tanzanian EEZ seafloor. Also, the potential for Tanzania to pose a claim for extending its continental shelf is discussed.
\end{abstract}

\section{INTRODUCTION}

Tanzania is situated between the great lakes of Victoria, Tanganyika and Nyasa on the northwest and western side, and the Indian Ocean on the eastern side and lies between $1^{\circ} \mathrm{S}$ and $11^{\circ} \mathrm{S}$. It consists of the mainland and three major islands in the Indian Ocean which are Unguja and Pemba (together known as Zanzibar) and Mafia islands. Tanzania is one of the largest countries in Africa and the mainland coastline is about $800 \mathrm{~km}$ [1]. Its continental shelf is narrow (less than $5 \mathrm{~km}$ ) except in the vicinity of relatively shallow Mafia and Zanzibar channels, where the shelf reaches widths of about $60 \mathrm{~km}$. The sediments of the continental shelf are generally sandy but become muddy near the river mouths.

Being a coastal country, in 1989, Tanzania established her exclusive economic zone [2]. The northernmost boundary of the Tanzanian EEZ is at $4.66^{\circ} \mathrm{S}$, the easternmost point on the eastern boundary is at $43.67^{\circ} \mathrm{E}$ and the southernmost point on the southern boundary is at $10.41^{\circ} \mathrm{S}$. The EEZ provides Tanzania an extra and exclusive opportunity to access resources and services from its marine and coastal environment, such as marine transportation, fisheries, tourism, marine mineral deposits, and others $[1,3]$. In particular, due to its appreciably longer coastline, there are many small and several large islands, Tanzania has conducive equatorial tropical climate, and it is potentially rich in coastal and marine resources.

One of the most important basic data of the ocean is bathymetry. Bathymetry data enables the identification of major features such as seamounts, ridges, canyons, faults, slopes etc, and mapping of their precise locations and properties [4]. Bathymetry data also enable us to understand the morphology of the continental and tidal shelf, continental slope, continental rise and the abyssal plain and characterize

*Address correspondence to this author at the Institute of Marine Sciences, University of Dar es Salaam, P.O. Box 668, Zanzibar, Tanzania;

E-mail:masalu@ims.udsm.ac.tz them. Additionally, bathymetry can be combined with other geophysical data for example magnetic and gravity data to study geophysical properties such as magnetic properties of oceanic features e.g., seamount, trench, seafloor etc [5-8]. Furthermore, bathymetry is known to influence many coastal and oceanographic processes such as sediment budget/processes [9-11], exchange of water masses in and between oceanic basins and mixing [12-15], oceanic current systems [1618], tidal dynamics [19-21] and others. Bathymetry data is thus also an integrating framework for multidisciplinary studies.

This paper investigates the bathymetry of the EEZ of Tanzania and describes its various features and characteristics. It is hoped that the understanding of the Tanzania's EEZ geomorphic features and characteristics will shade some light on the potentials for Tanzania to extend its outer limits of the continental shelf within the framework of article 76 of the United Nations Convention on the Law of the Sea i.e., UNCLOS [22].

\section{DATA AND METHODOLOGY}

For the purpose of this study, the study area is the Tanzania EEZ delimited as follows: the northernmost boundary at $4.5^{\circ} \mathrm{S}$, easternmost boundary at $44.0^{\circ} \mathrm{E}$, and the southernmost boundary at $10.5^{\circ} \mathrm{S}$ (Fig. 1).

Due to the lack of locally collected data that suitably covers the Tanzania EEZ, there are two global databases that could be considered to use. These the General Bathymetric Chart of the Oceans (GEBCO) Digital Atlas (GDA) and the ETOPO2 (Earth Topography 2') [23, 24]. ETOPO2 database is based on 2 (two) minutes grids of latitude and longitudes which offers a resolution of about $3.6 \mathrm{~km}$, while the Centenary edition of the GDA is based on 1 (one) minute grids of the same offering a resolution of $1.8 \mathrm{~km}$, given the location of the study area. This means that features up to $3.6 \mathrm{~km}$ and $1.8 \mathrm{~km}$ could have been missed when using ETOPO2 and 


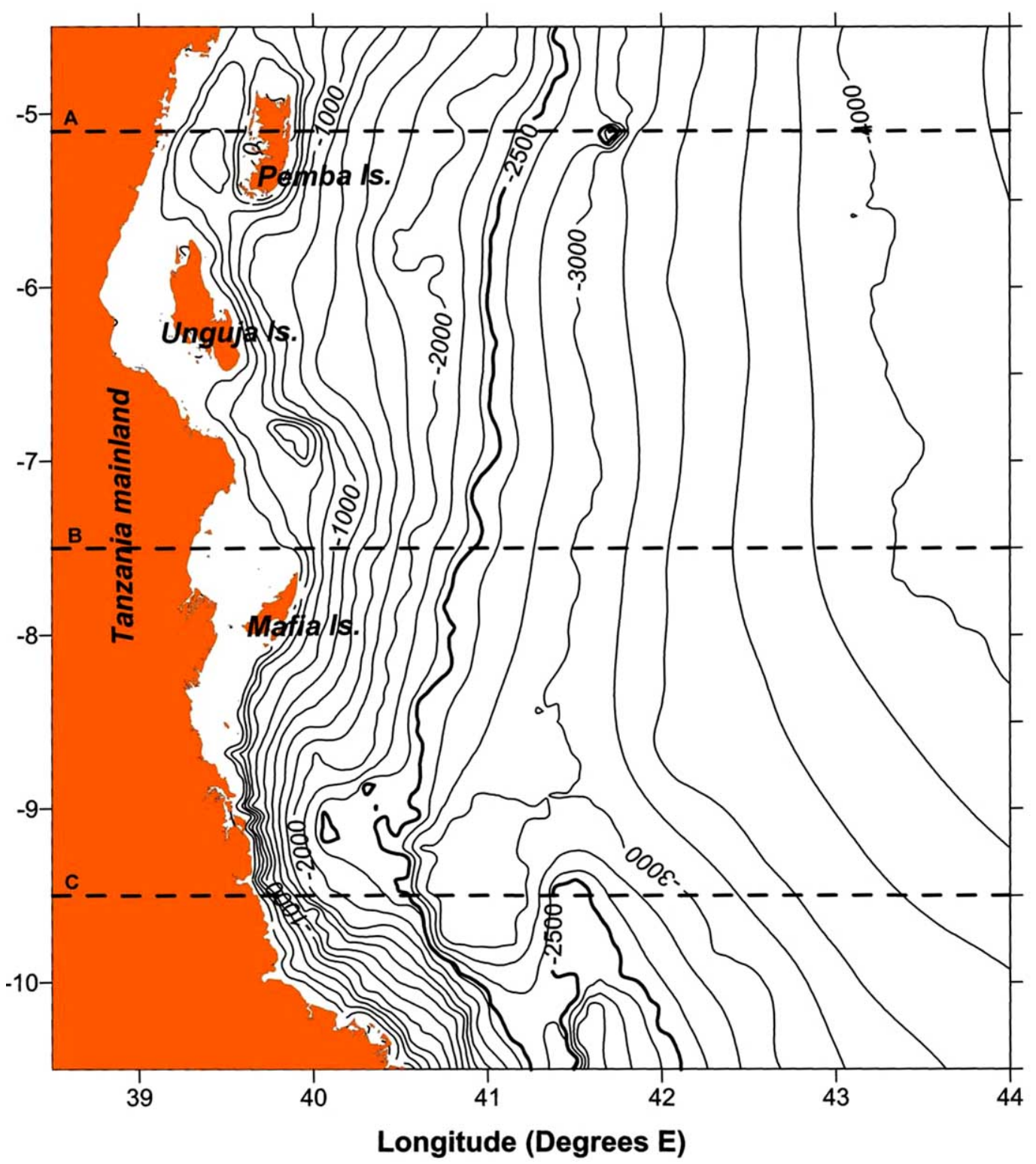

Fig. (1). Bathymetry map of the Tanzania EEZ at contour intervals of $200 \mathrm{~m}$. The $2500 \mathrm{~m}$ contour is shown by a thick line. The three dashed lines marked as A, B and $\mathbf{C}$ indicate the locations of profiles as shown in Fig. (2) that were used for detailed study of the bathymetry.

GDA databases respectively. As this study aims at identifying seafloor features within the study area, it was therefore decided to use the GDA database as it was more robust than ETOP2 in this case. However, it is important to note that the GDA has its other associated weaknesses; it is interpolated from $500 \mathrm{~m}$ contours that were digitized from paper charts [25]. Although, efforts have been made to add data from shallow water contours, generally its resolution and reliability in shallow water areas is poor. Additionally, bathymetric features up to $500 \mathrm{~m}$ in height could be missed if their base and peak fall just inside the $500 \mathrm{~m}$ contour level [26]. Furthermore, it is important to note that the GDA database is based on random tracklines of data from many different sources with highly variable quality and coverage, and many parts of the world oceans have not yet been mapped [26].

The GDA has its own built-in interface software that enables the user-selected extracts of the GEBCO data sets to be viewed in a variety of forms and projections. The software also enables user-selected extracts of data to be downloaded in a number of formats to use in user's own applications [24]. Using the GDA interface software bathymetric data within the Tanzania EEZ at grids of one minute, were downloaded into an xyz ASCII format for easy processing with other software. In this study, the data that were downloaded were processed by using the Surfer 8 and Grapher 4 softwares [27] which are powerful mapping and graphing software. First, the data were gridded using the surfer 8 software at grid size of 1 minute by 1 minute. This was done in order to maintain the resolution and quality of the data to that of the original database. Then the gridded data were contoured at the intervals of $200 \mathrm{~m}$ and three profiles were taken along the three sections (Fig. 1) for detailed study of the seafloor features. The profile sections were extracted and plotted (Fig. 2A, B \& C) using the Grapher 4 software. 


\section{RESULTS}

The seafloor in the study area (Fig. 1) appears to be gently inclined northeastward with the depth at northeast reaching slightly more than $4200 \mathrm{~m}$. The seafloor can be divided into three bathymetrical zones based on the changes of the slope of the seafloor. The steep seafloor with depths up to $500 \mathrm{~m}$ which includes the continental shelf and part of the continental rise, the moderately steep seafloor with depths between 500 and $3500 \mathrm{~m}$ that comprises part of the continental rise, and the gently dipping seafloor between 3500 and $4200 \mathrm{~m}$ that includes the abyssal plain (Fig. 1). The continental rise appears to be very steep along the southern coastline of Mainland Tanzania and less steep near major islands and along the northern coastline. The continental shelf is in general very narrow especially along the southern coastline of Mainland Tanzania. Based on the data used in this study, morphologically the Tanzania EEZ seafloor appears to be simple with no outstanding or complex features (Fig. 1). However, three distinct morphological features are identifiable on the seafloor. Firstly, an isolated feature that seems like a seamount appears to be located on the north of the study area (about $210 \mathrm{~km}$ east of Pemba Island) at $5.1^{\circ} \mathrm{S}$ and $41.7^{\circ} \mathrm{E}$ within the boundary of the continental rise and the abyssal plain (Fig. 1). The depth of the peak of this seamount is at $2250 \mathrm{~m}$ below sea level, the western flank depth is 2625 $\mathrm{m}$ and the eastern flank depth is $3125 \mathrm{~m}$ below sea level (Figs. 1 \& 2A). Secondly, at south near $41.5^{\circ} \mathrm{E}$ a ridge protrudes northwards into the study area from south. This ridge lies on the continental rise. Its axis depth varies from $2500 \mathrm{~m}$ to $1900 \mathrm{~m}$ below sea level. Finally, adjacent to the ridge, on the northwest a significant feature of a deep depression is found (Figs. 1 \& 2C). This depression is about $3000 \mathrm{~m}$ from sea level and about $600 \mathrm{~m}$ deep compared to the surrounding seafloor on the west, south and east sides. The bottom diameter of the depression is about $60 \mathrm{~km}$. Furthermore, the slopes of the depression are very steep on all sides except only on the northeastern side where the depression appears to open-up at the foot of the continental rise.

\section{DISCUSSION}

Bathymetry is one of the basic and important data in the study and understanding of the various oceanographic properties and behavior of our ocean and coastal environments such as currents, resources and their distribution. For more reliable and detailed information, bathymetry data of a good resolution is required.

Despite the limitations of the GDA database in terms of resolution, three distinctive morphological features were identified. First, a feature like an isolated seamount exists at $5.1^{\circ} \mathrm{S}$ and $41.7^{\circ} \mathrm{E}$. However, investigation of the recently published International Bathymetric Chart of the Western Indian Ocean [28] does not indicate any existence of a seamount around that location. There are two possibilities, that is, the feature could simply be a bug in the database or a real seamount. There is therefore a need to verify the existence or none-existence of the seamount. If the seamount exists, then the need to investigate its origin and/or geophysical properties would be in order. Based on the results and data used in this study, we can only speculate that if the seamount really exists, then based on its shape it is probably volcanic in origin. However, other geophysical data, e.g. magnetics, are needed to confirm this. We also can not rule out completely the other possible mechanism of seamount formation that may involve uplifting of a block of seafloor, though this mechanisms is not supported by the shape of the observed feature. Another feature that has been identified in this study is the depression at southwest of the study area. This depression is located on a very steep continental rise. Additionally, the depression is located only about $110 \mathrm{Km}$ from the very steep southern mainland coastline and lies close to another feature which is a ridge that protrudes into the study area from south. The depression could be volcanic in nature (crater) and may be related to the break-up of the Gondwanaland [29]. However, as noted before, additional geophysical data are needed to verify this. The ridge may play a key role in influencing the behavior and/or properties of ocean currents as well as sediment transport (e.g., [9]) in the area.

The GDA data used in this study is probably the best database available for the Tanzania EEZ bathymetry. Unfortunately, this database can not resolve small features that are sometimes very important. For example, in the GDA three canyons are indicated to be located along the southern coastline of mainland Tanzania (Table 1), but they can not be clearly seen on Fig. (1). Canyons are important in several ways. Geologically, they may play a key role in sediment transport and thus influence sediment budget of the surrounding area. Canyons are also important in national defense for submarine navigation and manipulation. What is more, canyons comprise an important ecosystem for the fossil fish coelacanth [30, 31], which has been caught many times in Tanzania $[32,33]$. The coastal area also consists of other important ecosystems such as seagrasses and coral reefs that need a backing of good resolution bathymetry data for their comprehensive study.

Furthermore, under Article 76 and Annex II to United Nations Convention on the Law of the Sea (UNCLOS), states are required to establish the outer limits of their continental shelf beyond 200 nautical miles from the baseline from which the breath of their territorial sea is measured [22]. This should be done by delineating clear maritime boundary limits in accordance with the Commission on the Limits of the Continental Shelf (CLCS) technical and scientific guidelines. To be able to do this states need original data and information, and bathymetry is the key data required. Recognizing the lack of data and information as well as expertise in most developing African countries to implement UNCLOS delineations, the UNESCO/IOC established a training project [34] to build the required relevant capacities in those countries. It is envisaged that after the training the CLCS in collaboration with other supporters will assist, requesting developing countries in mapping their continental shelf in their bid to extend their maritime boundaries.

Tanzania has already started working towards extending its maritime limits. These efforts include the establishment of the Tanzania Continental Shelf Delineation (TCSD) project. The project is guided by a national Steering Committee and a Technical Core Group. Several activities within these efforts have been done. These include capacity building training for the Technical Core Group and desktop studies to investigate the potentials for Tanzania to lodge a claim. The results of the present study show that the seafloor of the Tan- 

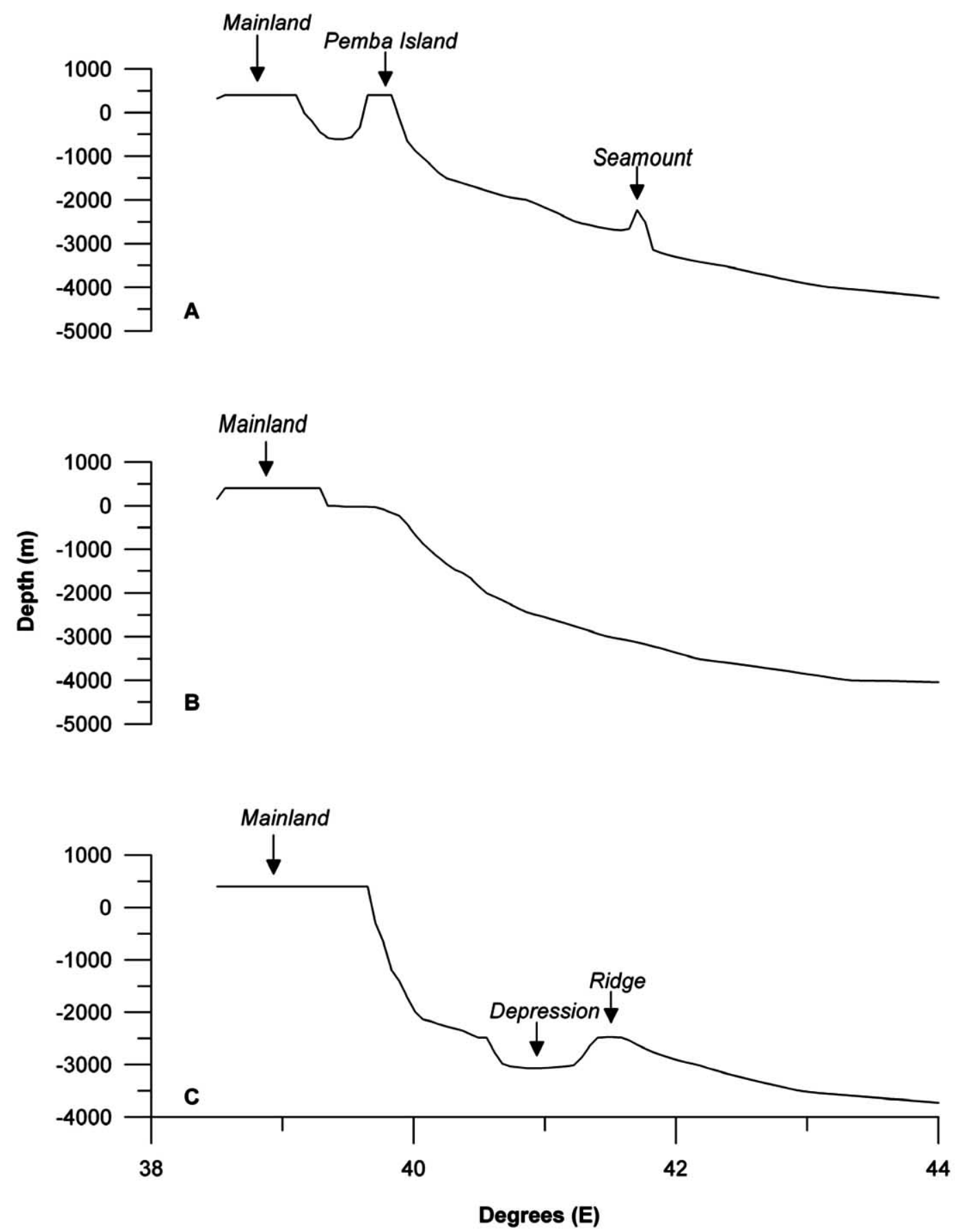

Fig. (2). Bathymetric profiles $\mathbf{A}, \mathbf{B}$, and $\mathbf{C}$ of the Tanzania EEZ at locations as indicated on Fig. (1). Profile $\mathbf{A}$ shows the feature of a seamount while profile $\mathbf{C}$ shows the depression and the ridge. Note the steep continental shelf on profile $\mathbf{C}$.

Tanzania EEZ is generally smooth and devoid of features that extend beyond the EEZ. This means Tanzania does not have physiographical features on the seafloor that could be used to pose a claim under UNCLOS. The UNCLOS process also requires documentation on the $2500 \mathrm{~m}$ isobaths which could be used to pose a claim if it lies beyond the EEZ. The present study indicates that the $2500 \mathrm{~m}$ isobath lies within the EEZ (Fig. 1) and therefore this criterion also does not pose an argument for extending the shelf boundaries. Furthermore, the UNCLOS process also deals with several other parameters including sediment thickness, foot of the slope and seafloor geology, which require acoustic or seismic surveying. The TCSD project Technical Core Group is currently working on these parameters including establishing the foot of the slope which is a major reference point for several of the UNCLOS related measurements.

Based on this study it is clear that there is an urgent need for Tanzania to do concerted efforts in mapping its coastal area and the EEZ in order to correctly understand and char- 
Table 1. Morphological features in the Tanzania EEZ

\begin{tabular}{|c|c|c|c|c|c|c|}
\hline S/No. & Type & Name & Location & Source & Year Found or Proposed & Proposed/Found by \\
\hline \hline 1 & Canyon & Lindi & $\begin{array}{c}39.92^{\circ} \mathrm{E} / 9.87^{\circ} \mathrm{S} \text { to } \\
40.50^{\circ} \mathrm{E} / 9.38^{\circ} \mathrm{S}\end{array}$ & IBCWIO 1.07 & $\begin{array}{c}\text { Prof. Jean-Rene Vanney } \\
\text { (Univ. of Paris-IV) }\end{array}$ \\
\hline 2 & Canyon & Mikindani & $\begin{array}{c}40.27^{\circ} \mathrm{E} / 9.97^{\circ} \mathrm{S} \text { to } \\
40.58^{\circ} \mathrm{E} / 9.67^{\circ} \mathrm{S}\end{array}$ & IBCWIO 1.07 & $\begin{array}{c}\text { Prof. Jean-Rene Vanney } \\
\text { (Univ. of Paris-IV) }\end{array}$ \\
\hline 3 & Canyon & Rovuma & $40.67^{\circ} \mathrm{E} / 10.33^{\circ} \mathrm{S}$ & IBCWIO 1.07 & 2000 & $\begin{array}{c}\text { Prof. Jean-Rene Vanney } \\
\text { (Univ. of Paris-IV) }\end{array}$ \\
\hline 4 & Seamount & Unnamed & $41.7^{\circ} \mathrm{E} / 5.1^{\circ}$ & This study & - & - \\
\hline 5 & Depression & Unnamed & $41.0^{\circ} \mathrm{E} / 9.5^{\circ} \mathrm{S}$ & This study & - & - \\
\hline 6 & Ridge & Unnamed & $41.5^{\circ} \mathrm{E}$ & This study & - \\
\hline
\end{tabular}

IBCWIO: International Bathymetric Chart of the Western Indian Ocean.

acterize the behavior, resources and their distribution of its ocean. This will also enable Tanzania to comply with international regulations and access the various opportunities and rights such as those stipulated by UNCLOS. However, for a country to make full utilization of the potentials in its EEZ needs to have some basic ocean capability in mapping, surveying and monitoring, and exploring its EEZ. Unfortunately, Tanzania's ocean capability is currently limited to coastal waters [3]. As a result of this, Tanzania does not reliably know the marine environment, characteristics and the potential of resources of its EEZ [3]. Building the basic ocean capability is a major challenge that Tanzania should endeavor to overcome.

\section{CONCLUSIONS}

We have investigated the bathymetry of the Tanzania EEZ using data extracted from the GDA. The Tanzania EEZ appears to be gently inclined northeastward. The Tanzania EEZ seafloor can be divided into three bathymetrical zones: (i) steep seafloor with depths between 0 and $500 \mathrm{~m}$, (ii) moderately steep seafloor with depths between 500 and 3500 $\mathrm{m}$, and (iii) gently dipping seafloor with depths between 3500 and $4200 \mathrm{~m}$. Morphologically, the Tanzania EEZ seafloor appears to be simple with no outstanding or complex features which could only reflect the resolution of the data used in this study. However, three distinct morphological features were identified: (i) an isolated seamount that is located on the north of the Tanzania EEZ at $5.1^{\circ} \mathrm{S} / 41.7^{\circ} \mathrm{E}$ (ii) a ridge that is oriented northwards located at south near $41.5^{\circ} \mathrm{E}$ and (iii) a circular depression located at $41.0^{\circ} \mathrm{E} / 9.5^{\circ} \mathrm{S}$. This study has underscored the importance of bathymetry data for multidisciplinary research/investigation of coastal and marine environment and the need for national efforts in mapping the EEZ by local initiatives (building the local ocean capability) and by making effective use of available international and/or regional opportunities and rights

\section{ACKNOWLEDGEMENTS}

I would like to thank the British Oceanographic Data Centre, IOC of UNESCO and IODE for making available the data used in this study, and for the training in data management and processing.

\section{REFERENCES}

[1] Masalu DCP. Coastal and marine resource use conflicts and sustainable development in Tanzania. Ocean Coastal Manage 2000a; 43: 475-94.

[2] URT (United Republic of Tanzania). The Territorial Sea and Exclusive Economic Zone Act. Government Printer, Dar es Salaam, Tanzania. 1989.

[3] Masalu DCP. $20^{\text {th }}$ anniversary of the Institute of Marine Sciences and marine science in Tanzania - what next step. Ocean Coastal Manage 2000b; 43: 963-72.

[4] Masalu DCP, Ogawa Y, Kobayashi K. Bathymetry of the Joban Seamount Chain, Northwest Pacific. Mar Geol 2001; 173: 87-96.

[5] Masalu DCP, Tamaki K, Kobayashi K. Paleomagnetism of the Joban seamount chain, Northwestern Pacific. J Geomag Geoelectr 1993; 45: 503-34.

[6] Masalu DCP, Tamaki K, Sager WW. Paleomagnetism of the Joban seamount chain: Its origin and tectonic implications for the Pacific plate. J Geophys Res 1997; 102: 5145-55.

[7] Honsho C, Tamaki K, Fujimoto H. Three-dimensional magnetic and gravity studies of the Rodriguez Triple Junction in the Indian Ocean. J Geophys Res 1996; 101: 15837-48.

[8] Tamaki K, Fujimoto H. Preliminary Cruise Report of the R/V Hakuho-Maru KH93-3, "Rodriguez Triple Junction Expedition in the Indian Ocean”. Ocean Research Institute, University of Tokyo, Japan, 1995; 183.

[9] Dubi AM, Nyandwi N. Preliminary studies for the mitigation and control of coastal erosion at Kunduchi beach Dar es Salaam. IMS Research Report Series 2000; Report No. IMS/1999/01: 72.

[10] Lane A. Bathymetric evolution of the Mersey Estuary, UK, 1906 1997: causes and effects. Estuar Coast Shelf Sci 2004; 59: 249-74.

[11] Dowdeswell JA. Continental slope morphology and sedimentary processes at the mouth of an Antarctic palaeo-ice stream. Mar Geol 2004; 204: 203-15.

[12] Schmitz WJ. On the interbasin-scale thermohaline circulation. Rev Geophys 1995; 33: 151-73.

[13] Gerdes R, Schauer U. Large-scale circulation and water mass distribution in the Arctic ocean from model results and observations. J Geophys Res 1997; 102: 8467-84.

[14] Webber DF, Webber MK, Williams DD. The relative importance of meteorological events, tidal activity and bathymetry to circulation and mixing in Kingston harbour, Jamaica. Bull Mar Sci 2003; 73: 273-90.

[15] Garabato CAN, Polzin KL, King BA, Heywood KJ, Visbeck M. Widespread intense turbulent mixing in the Southern Ocean. Science 2004; 303: 210-14.

[16] Bourke RH, Tunnicliffe MD, Newton JL, Paquette RG, Manley TO. Eddy near the Molloy Deep revisited. J Geophys Res 1987; 92: 6773-76.

[17] Thiede J, Pfirman S, Schenke HW, Reil W. Bathymetry of Molloy Deep: Fram Strait between Svalbard and Greenland. Mar Geophys Res 1990; 12: 197-214. 
[18] Manley TO. Branching of Atlantic water within the GreenlandSpitsbergen passage: An estimate of recirculation. J Geophys Res 1995; 100: 20627-34

[19] Prandle D. Relationships between tidal dynamics and bathymetry in strongly convergent estuaries. J Phys Oceanogr 2004; 33: 273850 .

[20] Elias E, Stive M, Bonekamp H, Cleveringa J. Tidal inlet dynamics in response to human intervention. Coast Eng $\mathrm{J} 2003$; 45: 629-59.

[21] van der Molen J, Gerrits J, de Swart HE. Modelling the morphodynamics of a tidal shelf sea. Cont Shelf Res 2004; 24: 483-508.

[22] UN (United Nations). Article 76 of the 1982 United Nations Convention on the Law of the Sea. 1982.

[23] NGDC (National Geophysical Data Center). ETOPO2 Global 2' Elevations. CD-ROM, 1 Disc. 2001.

[24] BODC (British Oceanographic Data Centre). GEBCO (General Bathymetric Chart of the Oceans) Digital Atlas Centenary Edition 1903-2003. Natural Environment Research Council, UK, CDROM, 2 Discs. 2003.

[25] Marks KM, Smith WHF. An evaluation of publicly available global bathymetry grids. Mar Geophy Res 2006; 27: 19-34.

[26] IOC, IHO, and BODC. User Guide to the Centenary Edition of the GEBCO Digital Atlas and its Data Sets", published on CD-ROM on behalf of the Intergovernmental Oceanographic Commission and the International Hydrographic Organization as part of the General Bathymetric Chart of Oceans; British Oceanographic Data Centre, Liverpool, 2003.
[27] Golden Software Inc. Surfer 8 - Countoring and 3D surface mapping for scientists and engineers. Golden Software Inc. Software CD-ROM. One Disc. 2002.

[28] IOC. International Bathymetric Chart of the Western Indian Ocean Chart No. 04, $1^{\text {st }}$ ed, Bundesamt fur Seeschiffahrt und Hydrographie, Germany. 1999.

[29] Hawkesworth C, Kelley S, Turner S, Le Roex A, Storey B. Mantle processes during Gondwana break-up and dispersal. J Afr Earth Sci 1999; 28(1): 239-61.

[30] Sink KJ, Boshoff W, Samaai T, Timm PG, Kerwath SE. Observations of the habitats and biodiversity of the submarine canyons at Sodwana Bay. S Afr J Sci 2006; 102(9): 466-74.

[31] Uken R, Green AN. Coelacanth (Latimeria chalumnae) resting traces in a cave floor, Chaka Canyon, South Africa, S Afr J Sci. 2006; 102(9): 474-5

[32] Pwani Yetu. Coelacanth still lives in the Western Indian Ocean. Pwani Yetu 2003; 20: July - Sept.

[33] Benno B, Verheij E, Stapley J, et al. Coelacanth (Latimeria Chalumnae Smith 1939) discoveries and conservation in Tanzania, S Afr J Sci 2006; 102(9): 486-90.

[34] IOC. IOC Training and Technology Transfer in Africa for the Implementation of Article 76 of the 1982 United Nations Convention on the Law of the Sea (UNCLOS). IOC UNCLOS article 76 Project Concept Paper. 2003.

(C) D.C.P. Masalu; Licensee Bentham Open.

This is an open access article licensed under the terms of the Creative Commons Attribution Non-Commercial License (http://creativecommons.org/licenses/ by-nc/3.0/) which permits unrestricted, non-commercial use, distribution and reproduction in any medium, provided the work is properly cited. 